Biospecies Vol. 11 No. 1, January 2018

\title{
Struktur Komunitas Fitoplankton di Perairan Muara Sungai Bengawan Solo, Ujung Pangkah, Jawa Timur
}

\section{(Phytoplankton community structure in estuary of Bengawan Solo River, Ujung Pangkah, East Java)}

\author{
R. Syafarina, R. Widodo ${ }^{1)}$, Sulistiono ${ }^{2)}$, Niken T. M. Pertiwi ${ }^{2)}$ \\ ${ }^{1)}$ Departemen Ilmu dan Teknologi Kelautan, Fakultas Perikanan dan Ilmu Kelautan \\ Institut Pertanian Bogor \\ ${ }^{2)}$ Departemen Manajemen Sumber daya Perairan, Fakultas Perikanan dan Ilmu Kelautan \\ Institut Pertanian Bogor
}

\begin{abstract}
Estuary is one of an aquatic ecosystem that has something unique, because it is a meeting area of the fresh and sea water. This study aimed to analyze phytoplankton structure community in estuary of Bengawan Solo River, conducted from January to June 2001 at ten stations distributing from river, estuary and sea. Data analysis was done to evaluate species composition, abundance, diversity, evenness, and dominance indices of the phytoplankton. Clustering based on the phytoplankton abundance was done by using Bray Curtis index. Based on the study, the phytoplankton in the estuary of Bengawan Solo River consisted of 5 classes and 33 species such as. Bacillariophyceae (19 species), Cyanophyceae (2 species), Crysophyceae (3 species), Chlorophyceae (3 species) and Dinophyceae (6 species). Phytoplankton abundance varied, at the river station was 1026-3005 inde/l, the estuary was 5098-19727 inde/l, and the sea was 4206-8697 inde/l. Diversity Index (H) was 0, 29-2, 24, Evenness Index (E) was 0, 02-0, 98, and Dominant Index (C) was 0, 12-0, and 88. There were 3 groups according to clustering analysis based on the phytoplankton abundance using Bray Curtis Index (55\%).
\end{abstract}

Keywords: Phytoplankton, community structure, estuary, Bengawan Solo River, East Java.

\begin{abstract}
Abstrak
Perairan muara sungai merupakan salah satu perairan yang memiliki keunikan karena merupakan pertemuan antara air tawar dengan air laut. Penelitian ini bertujuan untuk menganalisis struktur komunitas fitoplankton di perairan muara Sungai Bengawan Solo, Jawa Timur. Penelitian dilakukan dari Bulan Januari sampai Juni 2001, pada 10 stasiun yang tersebar dari sungai, muara dan laut. Analisis data dilakukan untuk menghitung komposisi jenis, kelimpahan, keragaman, keseragaman, dan dominansi. Untuk pengelompokan berdasarkan kelimpahan jenis fitoplankton, digunakan Indeks Bray-Curtis. Berdasarkan hasil pengamatan, fitoplankton di perairan muara Sungai Bengawan Solo terdiri atas 5 kelas dan 33 jenis, a.l. Bacillariophyceae (19 jenis), Cyanophyceae (2 jenis), Crysophyceae (3 jenis), Chlorophyceae (3 jenis) dan Dinophyceae (6 jenis). Kelimpahan fitoplankton bervariasi, pada stasiun di sungai berkisar 1026-3005 inde/l, muara berkisar 5098-2474 inde/l dan laut berkisar 4206-8697 inde/l. Indeks keanekaragaman $(\mathrm{H})$ berkisar 0,29-2,24, Indeks keseragaman (E) 0,02-0,98, dan Indeks dominansi (C) 0,12-0,88. Pengelompokan kelimpahan fitoplankton berdasarkan indeks Bray Curtis (pada taraf 55\%) terbentuk 3 kelompok.
\end{abstract}

Kata Kunci: Fitoplankton, struktur komunitas, muara, Sungai Bengawan Solo, Jawa Timur 


\section{PENDAHULUAN}

Muara sungai merupakan perairan yang memiliki keunikan karena merupakan pertemuan antara air tawar dan air laut. Daerah ini berperan sebagai daerah peralihan dari ekosistem perairan. Kondisi lingkungan perairan estuari mempunyai variasi yang besar dalam banyak parameter. Hal ini terlihat dari berfluktuasi nya salinitas, suhu, adanya pengaruh pasang-surut, dan masukan dari air tawar (Nybakken 1988). Keadaan ini menciptakan suatu lingkungan yang khas bagi organisme di estuari. Kebanyakan daerah ini didominasi oleh substrat yang berasal dari sedimen baik yang dibawa oleh air laut maupun air tawar yang terkadang membawa kandungan nutrient yang bermanfaat untuk pertumbuhan dan perkembangan organisme fitoplankton dan zooplankton. Organisme tersebut merupakan komponen biologi penting karena sebagai mata rantai pada siklus makanan di lingkungan perairan.

Plankton merupakan komponen biologis penting karena sebagai salah satu bagian dari mata rantai pada siklus makanan di lingkungan perairan. Jaring-jaring makanan yang terbentuk dimulai dari organisme renik. Organisme plankton (terutama fitoplankton) dapat langsung memanfaatkan unsur hara di perairan, melalui proses fotosintesis untuk menghasilkan energi yang dibutuhkan oleh organisme yang menduduki tingkat pemangsa berikutnya seperti zooplankton, udang, ikan, dan lain-lain.

Fitoplankton merupakan tumbuhan mikroskopis yang hidup melayang-layang dalam perairan dan pergerakannya mengikuti pergerakan arus. Pertumbuhan, perkembangan, penyebaran jenis-jenis dan komposisi serta kelimpahan fitoplankton sangat dipengaruhi oleh keadaan oseanografi baik fisika maupun kimia seperti: suhu, salinitas, kandungan fosfat, nitrat, silikat, arah, dan kecepatan arus serta penetrasi cahaya (Nybakken 1988). Fitoplankton merupakan penyumbang fotosintesis terbesar di laut. Tanpa adanya fitoplankton tidak ada kehidupan di dalam perairan

Beberapa penelitian berkaitan dengan fitoplankton di wilayah pantai, teluk dan muara telah dilakukan, a.l. fitoplankton di perairan Muara Angke (Jakarta) (Rismawan, 2000), fitoplankton di perairan Teluk Lampung (Mevita, 2001), dan fitoplankton di perairan mangrove Angke Kapuk, Jakarta utara (Retnani, 2001). Namun demikian penelitian berkaitan dengan kondisi fitoplankton di ekosistem estuari masih belum banyak diinformasikan .

Penelitian ini bertujuan untuk menganalisis struktur komunitas yang meliputi komposisi jenis, kelimpahan, indeks keanekaragaman, keseragaman, dan dominasi fitoplankton di perairan muara Sungai Bengawan Solo, Ujung Pangkah, Jawa Timur. 


\section{BAHAN DAN METODE}

\section{Waktu dan Tempat}

Penelitian ini dilakukan di sekitar perairan muara Sungai Bengawan Solo, Ujung Pangkah, Jawa Timur (Gambar 1), yang dimulai dari bulan Januari sampai Juni 2001. Contoh fitoplankton dan air yang diambil dari lokasi penelitian dibawa langsung dengan perlakuan ke laboratorium dan dianalisis. Analisis fitoplankton dan fisik-kimiawi air dilakukan di Laboratorium Avertebrata Air dan Limnologi, Departemen Manajemen Sumberdaya Perairan, Fakultas Perikanan dan Ilmu Kelautan, Institut Pertanian Bogor.

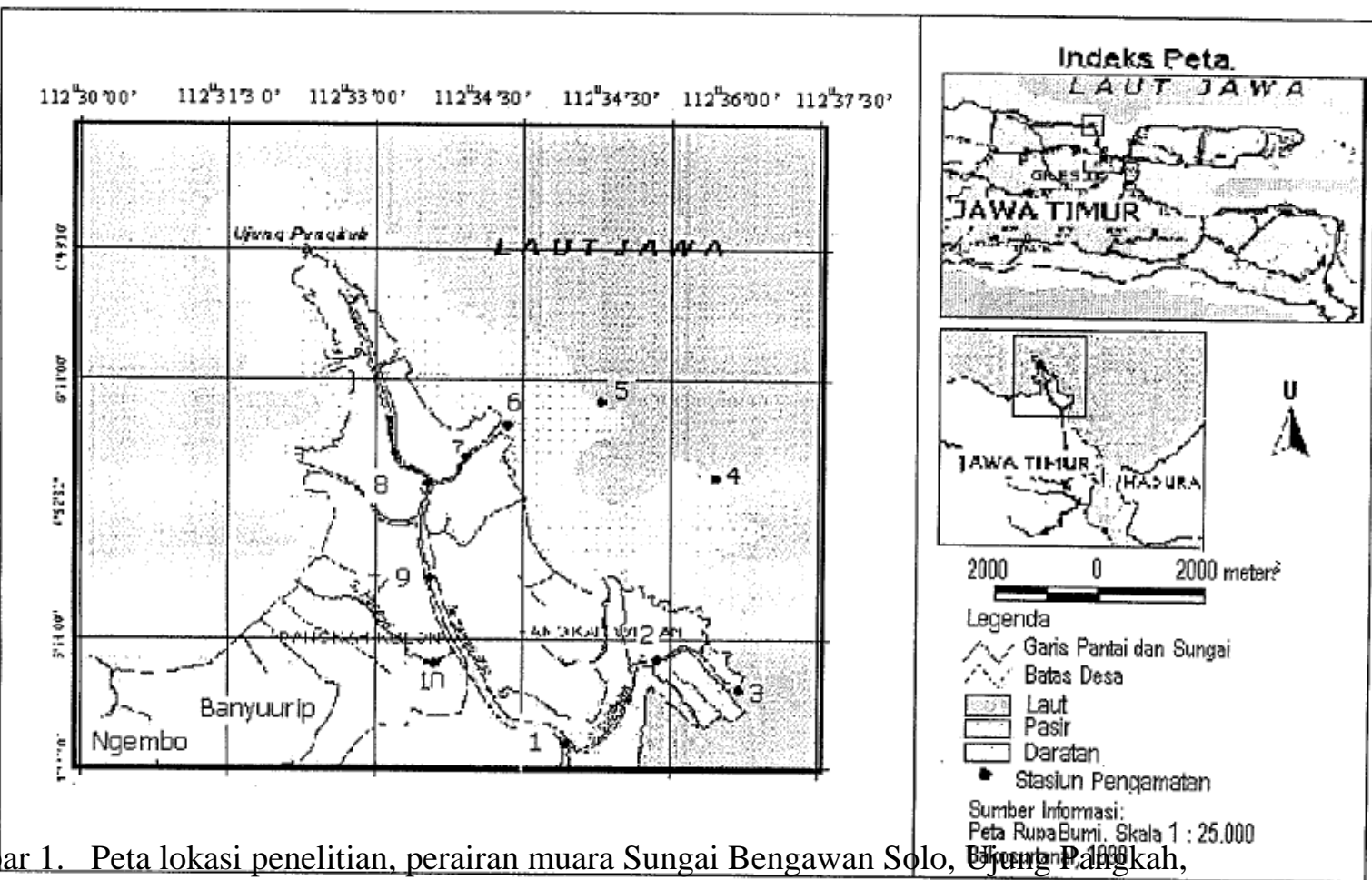

Gresik, Jawa Timur

\section{Alat dan Bahan}

Bahan yang digunakan pada penelitian ini meliputi contoh fitoplankton, contoh air, dan larutan lugol. Alat dan tempat analisis disajikan pada Tabel 1. 
Tabel 1. Alat dan tempat analisis parameter fisika, kimia, dan biologi perairan.

\begin{tabular}{|c|c|c|c|}
\hline Parameter & Unit & Alat/metode & Tempat \\
\hline $\begin{aligned} \text { Fisika } & \\
- & \text { Suhu } \\
- & \text { Kecerahan } \\
- & \text { Arus }\end{aligned}$ & $\begin{array}{l}{ }^{\circ} \mathrm{C} \\
\% \\
\mathrm{~cm} / \mathrm{det}\end{array}$ & $\begin{array}{l}\text { Termometer } \\
\text { Secchi disk } \\
\text { Floating drouge }\end{array}$ & $\begin{array}{l}\text { In situ } \\
\text { In situ } \\
\text { In situ }\end{array}$ \\
\hline $\begin{array}{cl}\text { Kimia } & \\
- & \text { Salinitas } \\
- & \text { Nitrat } \\
- & \text { Fosfat } \\
- & \text { Silikat } \\
\end{array}$ & $\begin{array}{l}\% \text { o } \\
\text { ppm } \\
\text { ppm } \\
\text { ppm }\end{array}$ & $\begin{array}{l}\text { Refraktometer } \\
\text { Spektrofotometer } \\
\text { Spektrofotometer } \\
\text { Spektrofotometer }\end{array}$ & $\begin{array}{l}\text { In situ } \\
\text { Laboratorium } \\
\text { Laboratorium } \\
\text { Laboratorium }\end{array}$ \\
\hline $\begin{array}{l}\text { Biologi } \\
\quad-\quad \text { Fitoplankton }\end{array}$ & ind/l & $\begin{array}{l}\text { Plankton net, mikroskop binokuler, } \\
\text { dan buku identifikasi plankton }\end{array}$ & Laboratorium \\
\hline
\end{tabular}

\section{Pengambilan Contoh}

Pengambilan contoh fitoplankton dan sampel air dilakukan pada 10 stasiun pengamatan secara horizontal dari arah sungai menuju laut dimana pada setiap stasiun pengamatan 100 liter (1) air laut disaring, untuk diambil contoh fitoplanktonnya. Stasiun 1, 2, 7, 8, 9 dan 10 merupakan stasiun yang berhubungan dengan sungai, Stasiun 3 dan 6 merupakan stasiun muara sungai, dan Stasiun 4 dan 5 merupakan stasiun di wilayah laut. Contoh fitoplankton tersebut diawetkan dengan larutan lugol sebanyak delapan tetes. Penyaringan contoh fitoplankton dilakukan dengan menggunakan plankton net berukuran 25 (ukuran mesh size 64 um). Identifikasi fitoplankton dilakukan di laboratorium dengan menggunakan mikroskop binokuler dan buku identifikasi plankton Yamaji
(1966) dan Davis (1955). Perhitungan fitoplankton tiap genera dilakukan pada saat identifikasi untuk dianalisis kelimpahan, indeks keanekaragaman, indeks keseragaman, dan indeks dominansi.

\section{Analisis Data}

\section{Kelimpahan fitoplankton}

Kelimpahan fitoplankton adalah jumlah individu per satuan volume (dalam liter). Kelimpahan tersebut dapat dihitung dengan menggunakan metode Sedgwick-Rafter Counting Cell dan menggunakan mikorskop binokuler. SedgwickRafter Counting Cell adalah suatu alat yang digunakan untuk menganalisis plankton berukuran $50 \mathrm{~mm}, 20 \mathrm{~mm}$, dan tinggi $1 \mathrm{~mm}$. Volume Sedgwick-Rafter Counting Cell adalah 
$1000 \mathrm{~mm}^{3}$ atau $1 \mathrm{ml}$. Dalam mengamati fitoplankton, air contoh dimasukan ke dalam alat ini kemudian diamati di bawah mikroskop.

$$
\text { Perhitungan dan pengamatan }
$$

fitoplankton dilakukan sebanyak 10 petak dari Sedgwick-Rafter dengan tiga kali ulangan. Luas total petak adalah $200 \mathrm{~mm}^{2}$ (10 petak x $20 \mathrm{~mm}$ ). Sedangkan volume total petak adalah $200 \mathrm{~mm}^{3}$ yaitu, luas total petak x tinggi (1 mm) SedgwickRafter. Jumlah fitoplankton per liter adalah:

$$
\mathrm{N}=\mathrm{n} \times \mathrm{A} / \mathrm{B} \times \mathrm{C} / \mathrm{D} \times 1 / \mathrm{E}
$$

\section{Keterangan:}

$\mathrm{N}=$ Jumlah individu tercacah

$\mathrm{A}=$ Volume Sedgwick-Rafter Counting Cell $\left(1000 \mathrm{~mm}^{3}\right)$

$\mathrm{B}=$ Volume total petak yang diamati $\left(200 \mathrm{~mm}^{3}\right)$

$\mathrm{C}=$ Volume sampel yang tersaring $(30 \mathrm{ml})$

$\mathrm{D}=$ Volume Counting Cell $(1 \mathrm{ml})$

$\mathrm{E}=$ Volume sampel yang disaring (100 liter)

\section{Indeks keanekaragaman (H')}

Indeks keanekaragaman adalah suatu gambaran secara matematik yang melukiskan struktur komunitas fitoplankton yang dapat mempermudah menganalisis informasi tentang jenis dan jumlah jenis organisma tersebut. Semakin banyak jenis fitoplankton yang terdapat dalam suatu perairan, semakin besar keanekaragamannya. Perhitungan indeks keanekaragaman dilakukan dengan menggunakan Indeks Shannon-Wiener (Magurran 1955).
$H^{\prime}=-\sum_{i=1}^{n} p_{i} \ln p_{i}$

Keterangan:

H' = Indeks keanekaragaman Shannon-Wiener

$\mathrm{Pi}=n \mathrm{i} / \mathrm{N}$

$\mathrm{Ni}=$ Jumlah individu jenis ke-i

$\mathrm{N}=$ Jumlah total individu jenis ke-i

$\mathrm{S}=$ Jumlah jenis biota

Berdasarkan rumus di atas, indeks keanekaragaman Shannon-Wiener dikategorikan sebagai berikut:

$$
\begin{aligned}
& \mathrm{H}^{\prime}<1 \quad \text { Keanekaragaman rendah } \\
& 1<\mathrm{H}^{\prime}<3 \text { Keanekaragaman sedang } \\
& \mathrm{H}^{\prime}>3 \quad \text { Keanekaragaman tinggi }
\end{aligned}
$$

\section{Indeks keseragaman (E)}

Indeks ini digunakan untuk mengetahui keberadaan jenis yang mendominasi populasi dan untuk mengetahui penyebaran jumlah individu tiap jenis (Odum 1971). Hal ini dilakukan dengan membandingkan indeks keanekaragaman dengan nilai maksimumnya.

$\mathrm{E}=\frac{\mathrm{H}^{\mathrm{T}}}{\mathrm{H}_{\mathrm{maks}}^{\mathrm{T}}}$

Keterangan:

$$
\begin{array}{ll}
\mathrm{E} & =\text { Indeks keseragaman } \\
\mathrm{H}^{\prime} \text { maks } & =\text { Ln S } \\
\mathrm{S} & =\text { Jumlah jenis biota }
\end{array}
$$

Nilai E berkisar antara 0 dan 1 . Semakin kecil nilai E, semakin kecil pula nilai keseragaman fitoplankton. Hal ini menunjukan penyebaran jumlah individu tiap jenis tidak 
sama dan ada kemungkinan populasi tersebut didominasi oleh suatu jenis fitoplankton. Sebaliknya, semakin besar nilai E, maka keseragaman populasi fitoplankton semakin tinggi. Hal ini menunjukan jumlah jenis individu tiap jenis sama, dimana populasi tersebut tidak didominasi oleh suatu jenis fitoplankton.

\section{Indeks dominansi (C)}

Indeks dominansi yang digunakan adalah indeks dominansi Simpson (Simpson 1949 in Krebs 1989) sebagai berikut:

$c=\sum_{n=1}^{n}\left(\frac{n i}{N}\right)^{2}$

Keterangan:

$\mathrm{C}=$ Indeks dominansi Simpson

$\mathrm{ni}=$ Jumlah individu jenis ke-i

$\mathrm{N}=$ Jumlah total individu jenis ke-i

$\mathrm{S}=$ Jumlah jenis biota

Nilai C dikategorikan sebagai berikut:

$0<\mathrm{C}<0.5$ dominansi rendah

$0.5<\mathrm{C}<0.75$ dominansi sedang

$0.75<\mathrm{C}<1 \quad$ dominansi tinggi

\section{Pengelompokkan Kelimpahan Jenis Fitoplankton}

Untuk mengetahui pengelompokan jenis fitoplankton antar stasiun pengamatan digunakan indeks Bray-Curtis (Legendre dan Legendre 1983):

$$
\text { Ib }=1-\sum_{i=1}^{s} \frac{|A i j-B i k|}{|A i j+B i k|}
$$

Keterangan:

Ic = Nilai kesamaan Indeks Bray-Curtis

Aij = Nilai data parameter ke-i pada stasiun kej

Bik = Nilai data parameter ke-i pada stasiun ke-k

$\mathrm{S}=$ Jumlah taksa

\section{HASIL DAN PEMBAHASAN}

\section{Komposisi Fitoplankton}

Berdasarkan hasil pengamatan yang dilakukan selama 6 bulan (januari-Juni 2001), komposisi jenis fitoplankton di perairan muara Sungai Bengawan Solo (Gresik, Jawa Timur) terdiri dari 5 kelas dan 33 jenis. Kelas yang ditemukan yaitu Bacillariophyceae (19 jenis), Cyanophyceae (2 jenis), Crysophyceae (3 jenis), Chlorophyceae (3 jenis), dan Dinophyceae (6 jenis) (Tabel 2).

Tabel 2. Berberapa jenis fitoplankton yang ditemukan di muara Sungai Bengawan Solo, Ujung

Pangkah, Gresik, Jawa Timur. 


\begin{tabular}{lc}
\hline Bacillariophyceae & Dinophyceae \\
Skeletonema $\mathrm{sp}$ & Prorocentrum $\mathrm{sp}$ \\
Chaetoceros $\mathrm{sp}$ & Gymnodinium $\mathrm{sp}$ \\
Asterionella $\mathrm{sp}$ & Prorocentrum $\mathrm{sp}$ \\
Coscinodiscus $\mathrm{sp}$ & Pyrocystis $\mathrm{sp}$ \\
Pleurosigma $\mathrm{sp}$ & Ceratium $\mathrm{sp}$ \\
Dytilum $\mathrm{sp}$ & Peridinium $\mathrm{sp}$ \\
Bacteriastrum $\mathrm{sp}$ & Cyanophyceae \\
Hemiaulus $\mathrm{sp}$ & Pelagotrhrix $\mathrm{sp}$ \\
Nitzschia $\mathrm{sp}$ & Tricodesmium $\mathrm{sp}$ \\
Thalassionema $\mathrm{sp}$ & \\
Bacillaria $\mathrm{sp}$ & \\
Triceratium $\mathrm{sp}$ & Chromullina $\mathrm{sp}$ \\
Thalassiothrix $\mathrm{sp}$ & Distephanus $\mathrm{sp}$ \\
Rhizosolenia $\mathrm{sp}$ & Crysophyceae \\
Cerataulina $\mathrm{sp}$ & Silicoflagellata $\mathrm{sp}$ \\
Biddulphia $\mathrm{sp}$ & Chlorophyceae \\
Gyrosigma $\mathrm{sp}$ & Halosphaera $\mathrm{sp}$ \\
Leptocylindricus $\mathrm{sp}$ & Scenedesmus $\mathrm{sp}$ \\
Bellarochia $\mathrm{sp}$ & Actinastrum $\mathrm{sp}$ \\
&
\end{tabular}

Berdasarkan lokasi pengamatan, jenis Chlorophyceae. Sedangkan jenis fitoplankton fitoplankton dari kelas Bacillariophyceae yang paling sedikit ditemukan adalah dari Kelas ditemukan paling banyak dari seluruh stasiun Cyanophyceae. Jenis Bacillariophyceae juga pengamatan, kemudian diikuti kelas ditemukan paling banyak pada setiap sampling Dinophyceae, Crysophyceae dan (Januari - Juni 2001).

a

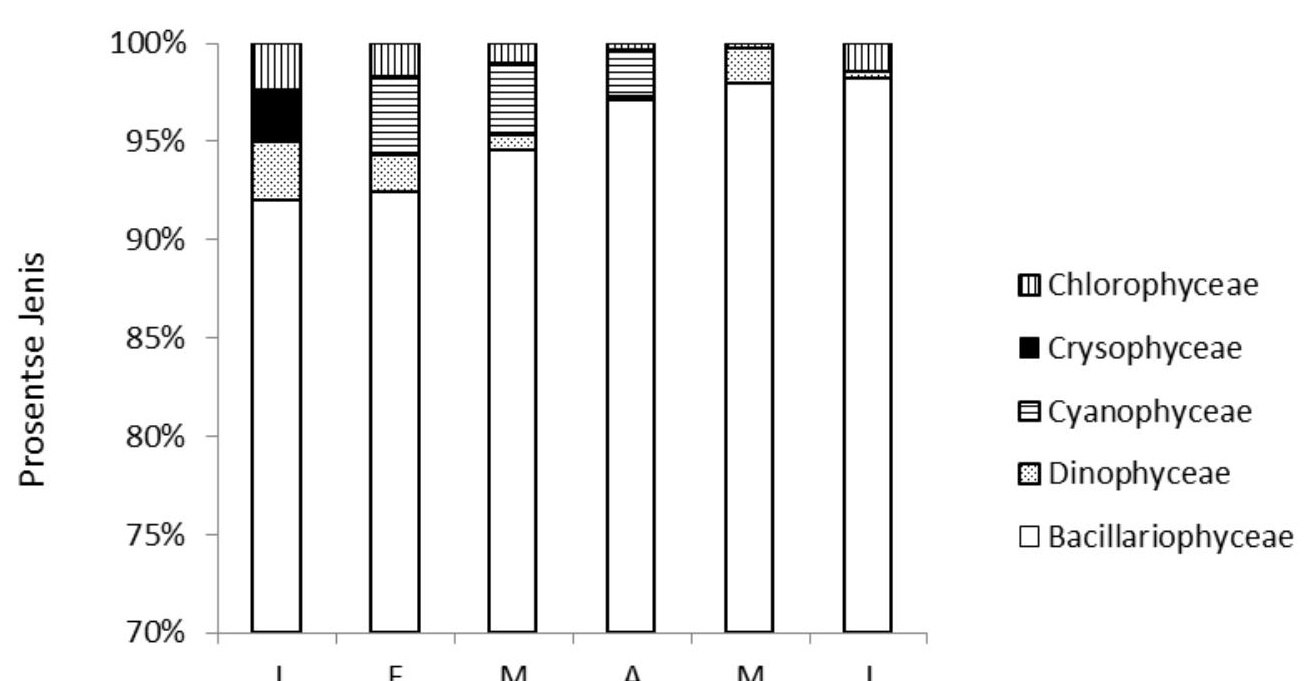




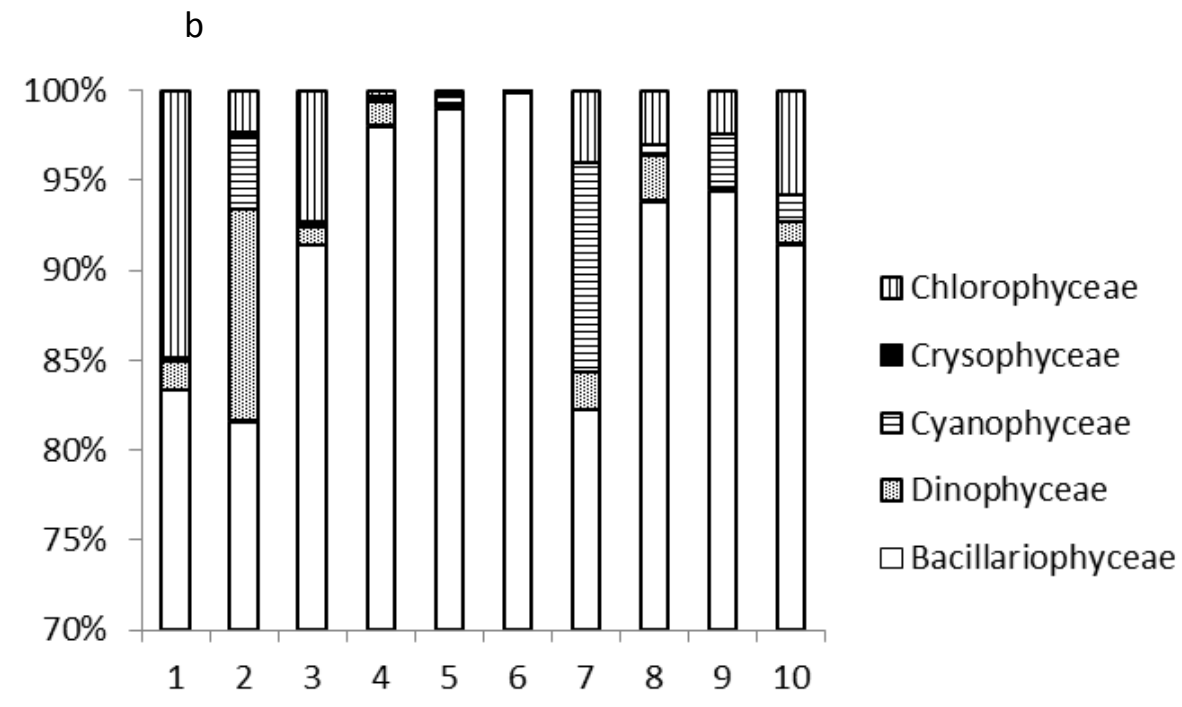

Stasiun
Gambar 2. Komposisi rata-rata fitoplankton berdasarkan waktu pengamatan (a) dan lokasi pengamatan (b) di perairan muara Sungai Bengawan Solo

Berdasarkan data yang diperoleh, komposisi Bacillariophyceae semakin meningkat jika dilihat dari stasiun yang berada di perairan dari arah sungai (Stasiun 1, 2, 67, 8, 9, dan 10) menuju muara (Stasiun 3 dan 6). Jenis Skeletonema sp dan Chaetoceros sp merupakan jenis yang paling banyak ditemukan. Meskipun jenis Bacillariophyceae merupakan jenis yang paling banyak ditemukan pada setiap stasiun. Namun pada Stasiun 7, jenis Cyanophyceae ditemukan dalam jumlah cukup banyak.

Berdasarkan komposisi fitoplankton tersebut, terlihat bahwa fitoplankton kelas Bacillariophyceae ditemukan dalam jumlah yang lebih banyak dibandingkan dengan kelas yang lain, baik berdasarkan waktu pengamatan maupun lokasi pengamatan. Kelas Bacillariophyceae ditemukan cukup banyak pada stasiun yang berada di daerah muara dan laut. Sedangkan pada aliran Sungai Bengawan Solo (Stasiun 1, 2, dan 7) jenis Bacillariophyceae lebih rendah dibandingkan stasiun lainnya (Gambar 2).

Komposisi jenis fitoplankton di perairan muara Sungai Bengawan Solo secara horizontal dari sepanjang aliran Sungai Bengawan Solo menuju laut menunjukan peningkatan. Hal ini terlihat dari komposisi fitoplankton kelas 
Bacillariophyceae yang semakin meningkat ke arah laut terutama pada Stasiun 3 dan 6 (yang terletak di muara) serta Stasiun 4 dan 5 (yang berada di laut). Sebaliknya pada fitoplankton

\section{Kelimpahan Fitoplankton}

Kelimpahan fitoplankton secara umum di perairan muara Sungai Bengawan Solo berkisar antara 86-62006 ind/l. Kelimpahan yang kecil dijumpai pada Stasiun 2 (Bulan Januari), dan kelimpahan yang tinggi dijumpai pada Stasiun 6 (Bulan Juni). Jika dihitung secara rata-rata per stasiun, kelimpahan yang cukup tinggi juuga dijumpai pada Stasiun 6, sedangkan yang kecil dijumpai pada Stasiun 2.

Kelimpahan fitoplankton di lokasi penelitian ini terbagi dalam 3 kelompok, yaitu stasiun yang berada di sepanjang aliran utama Sungai Bengawan Solo (Stasiun 1, 7, 8, dan 9), Sungai Ngapuri (Stasiun 10), dan Sungai
Cyanophyceae dan Chlorophyceae komposisinya cenderung menurun dan berada dalam jumlah yang kecil di Stasiun 6 (Gambar 2).

Sumbalan (Stasiun 2), stasiun yang berada di sekitar muara (Stasiun 3 dan 6) dan stasiun yang terletak di laut (Stasiun 4 dan 5). Kelimpahan rata-rata fitoplankton pada stasiun-stasiun yang terletak di sepanjang Sungai Bengawan Solo tersebut berkisar 1026-3005 ind/l, di muara berkisar 5098-24744 ind/1, dan di laut berkisar 4206-8697 ind/l. Berdasarkan waktu pengamatan, kelimpahan fitoplankton yang cukup besar dijumpai pada Bulan Juni, sedangkan kelimpahan yang sedikit dijumpai pada Bulan Januari. 

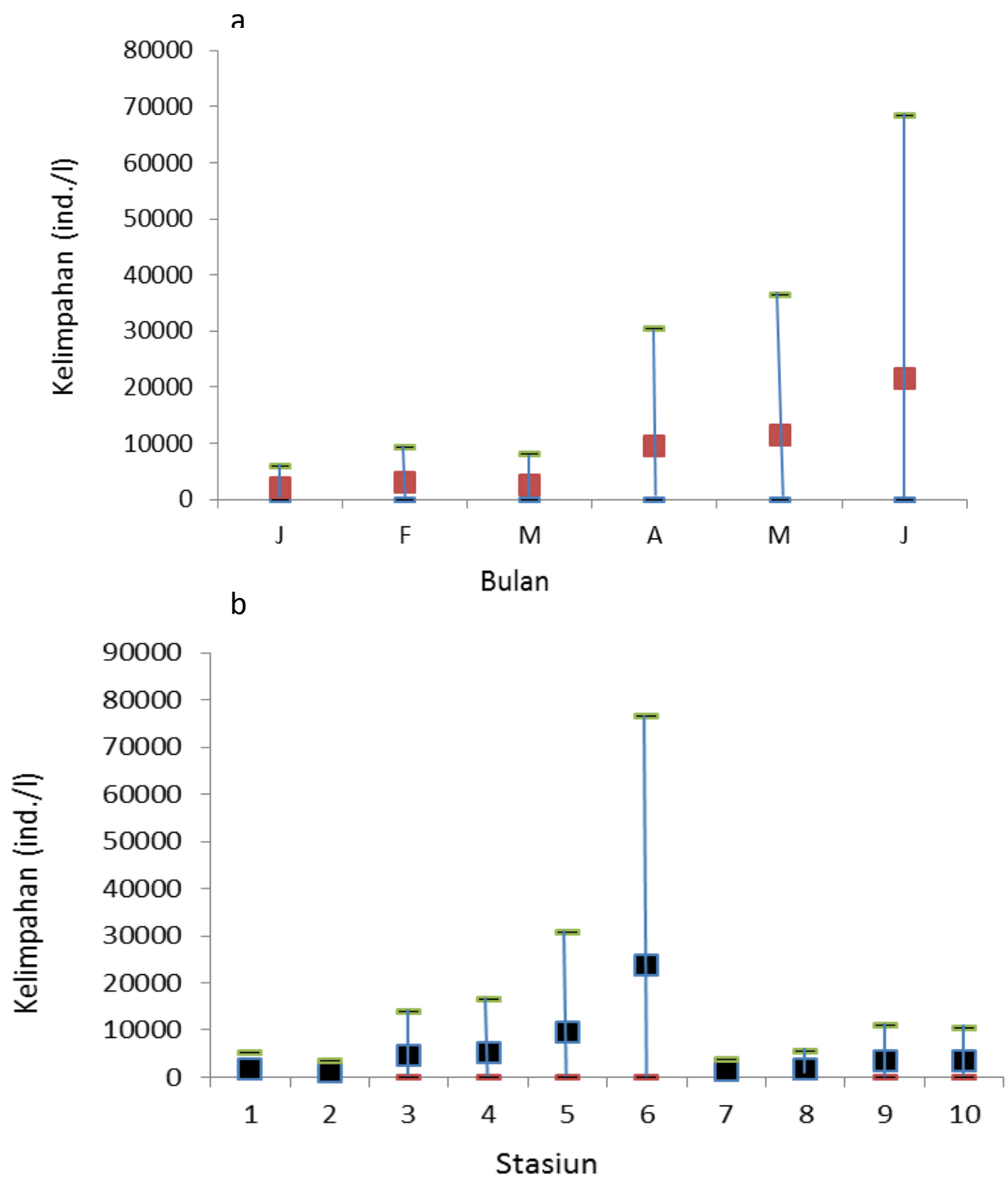

Gambar 3. Kelimpahan rata-rata fitoplankton berdasarkan waktu pengamatan (a) dan lokasi pengamatan (b) di perairan Muara Sungai Bengawan Solo

\subsubsection{Indeks Keanekaragaman, Keseragaman, dan Dominansi}

Berdasarkan waktu pengamatan, indeks keanekaragaman fitoplankton berkisar 0,33 -
2,44. Nilai yang cukup tinggi dijumpai pada

Bulan Januari, dan nilai yang rendah dijumpai 

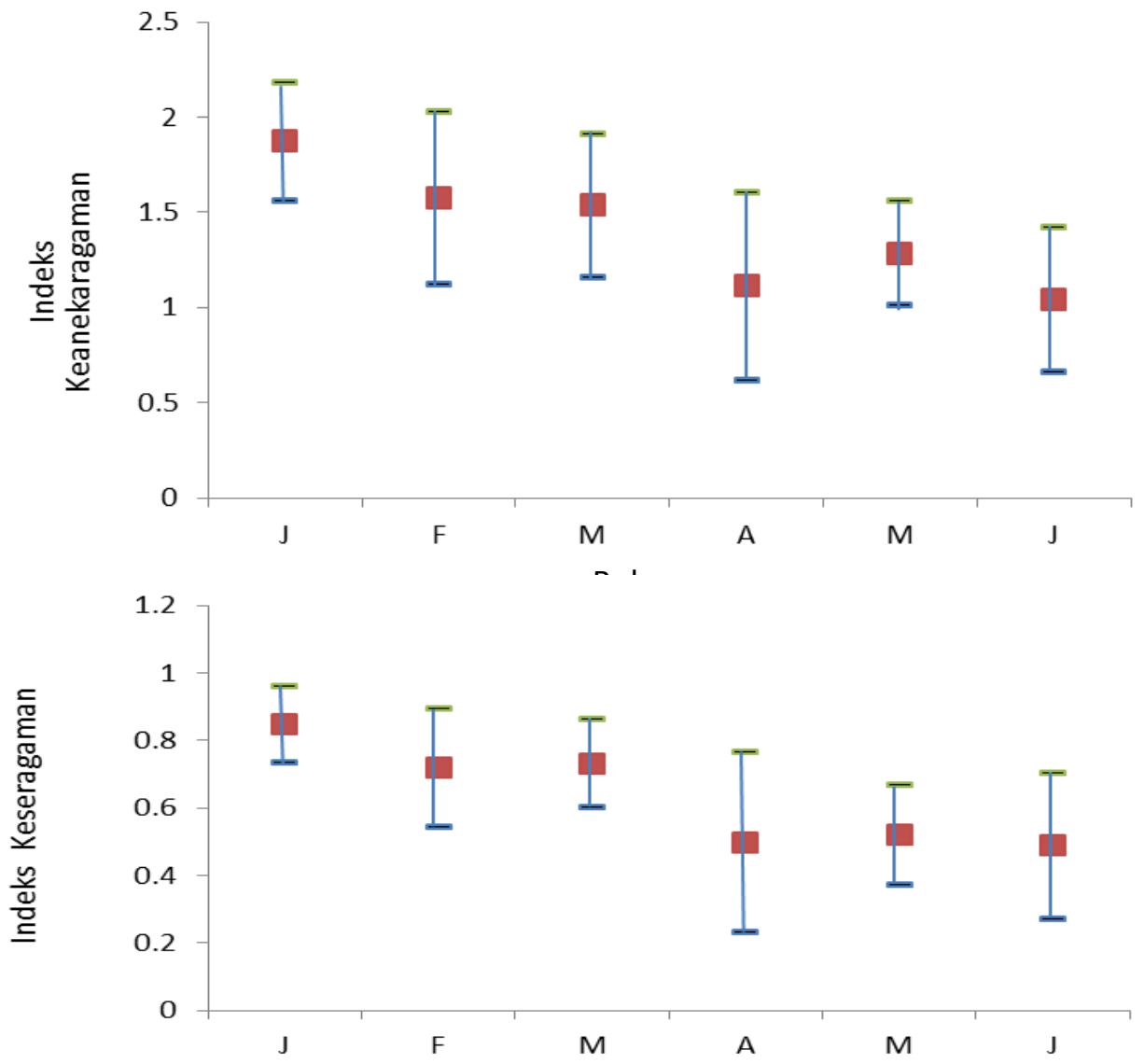

Bulan

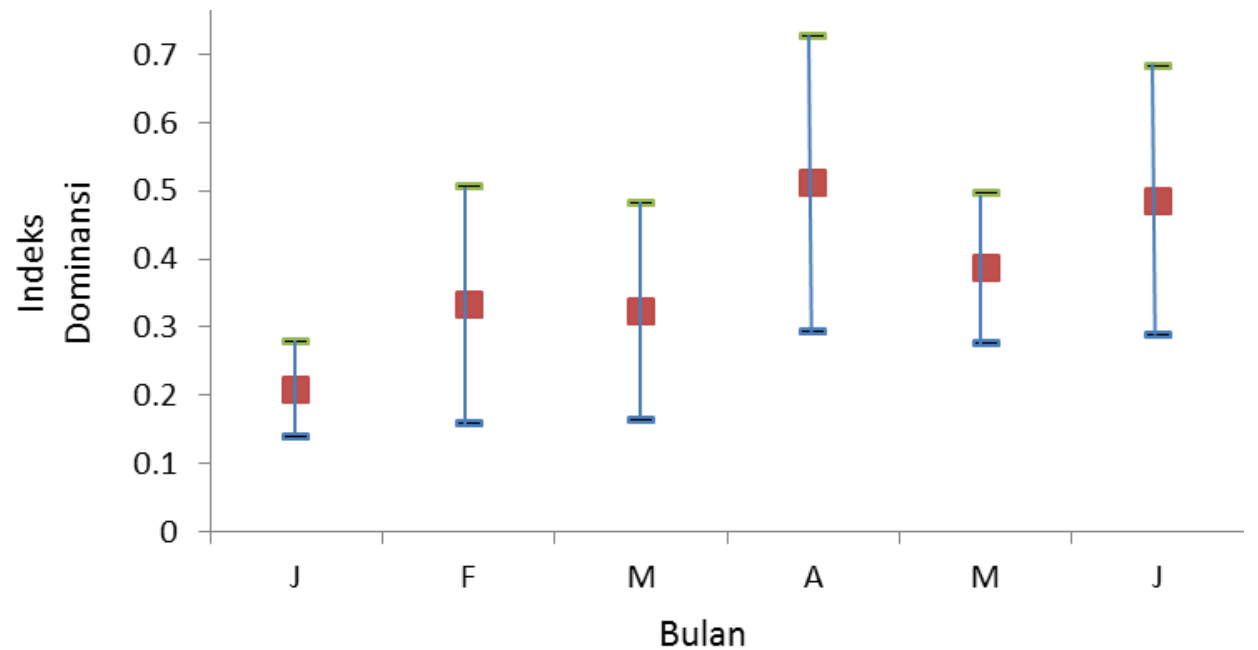


Gambar 4 Grafik indeks keanekaragaman, keseragaman, dan dominansi rata-rata di perairan muara Sungai Bengawan Solo

pada Bulan April. Indeks keseragaman berkisar $0,02-0,97$. Nilai yang cukup tinggi dijumpai pada Bulan Januari dan nilai yang rendah dijumpai pada Bulan April. Sedangkan Indeks dominansi berkisar 0,12.- 0,88. Nilai yang cukup tinggi dijumpai pada Bulan April dan nilai yang rendah dijum ai pada Bulan Januari.

Berdasarkan lokasi pengambilan contoh, nilai indeks keanekaragaman berkisar 1,01- 1,59 Nilai yang cukup tinggi dijumpai pada Stasiun 10 dan yang cukup rendah dijumpai pada Stasiun 6. Nilai indeks keseragaman berkisar $0,44-0,73$. Nilai yang cukup tinggi dijumpai pada Stasiun 2, dan yang cukup rendah dijumpai pada Stasiun 6. Sedangkan indeks dominansi berkisar 0,295 - 0,54. Nilai yang cukup tinggi dijumpai pada Stasiun 6, dan yang rendah dijumpai pada Stasiun 2.

Nilai indeks keanekaragaman dan keseragaman dari arah sungai ke muara secara horizontal cenderung menurun (Gambar 4) dan meningkat pada lokasi stasiun di laut. Penurunan nilai indeks keanekaragaman menunjukkan perairan muara Sungai Bengawan Solo didominasi oleh jenis tertentu. Jenis fitoplankton yang mendominasi adalah Skeletonema sp (1$29 \%)$ dan Chaetoceros sp (0.15-9.5\%).

\section{Pengelompokan Stasiun berdasarkan} Kelimpahan Jenis Fitoplankton

Pengelompokan stasiun berdasarkan parameter biologi dihitung dengan menggunakan indeks Bray-Curtis. Dari hasil perhitungan terbentuk dendrogram similaritas rata-rata dimana pada taraf kesamaan 55\% terbentuk 3 kelompok besar (Gambar 5). Kelompok 1 terdiri dari Stasiun 3, 9, 10, 4 (Kelompok sungai-estuari; dengan similaritas rata-rata sebesar $66.1 \%$ ), Kelompok 2 terdiri dari Stasiun 2, 7, 1, 8 (Kelompok sungai; dengan similaritas rata-rata sebesar 58.2\%) dan Kelompok 3 yang terdiri atas Stasiun 5 dan 6 (Kelompok estuari-laut; dengan tingkat kesamaan rata-rata sebesar 54.3\%). 


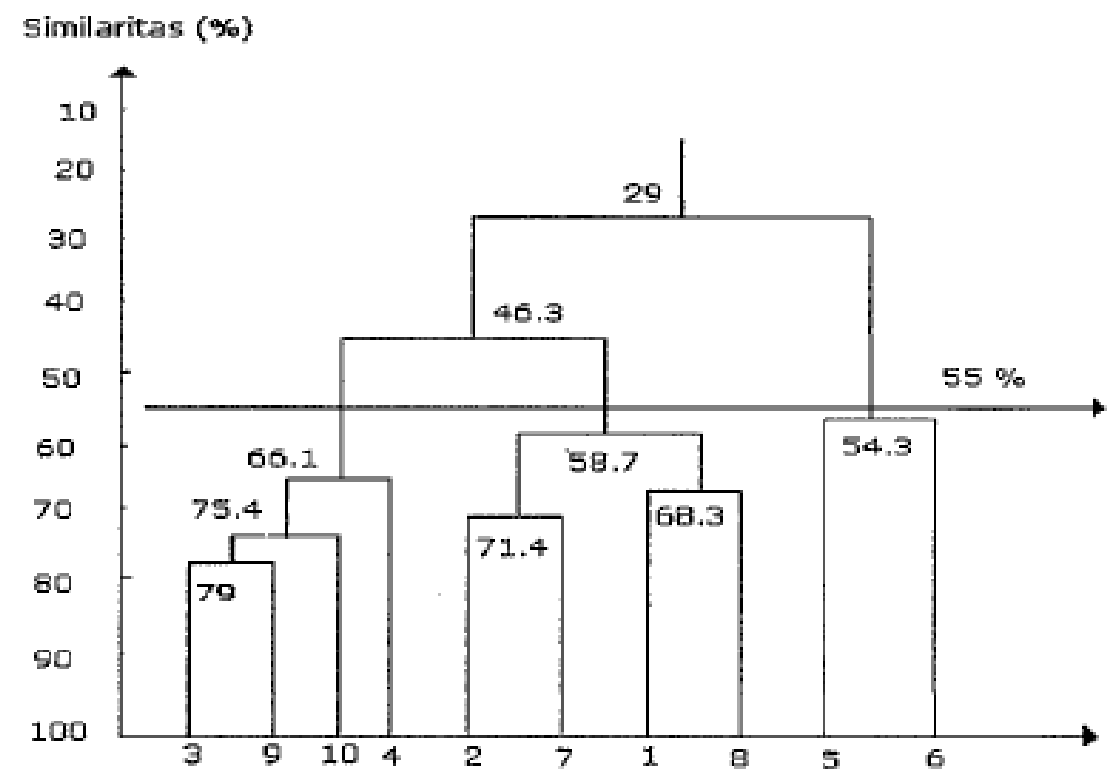

Gambar 5 Dendrogram similaritas Bray-Curtis

\section{Lingkungan Perairan}

Hasil pengamatan yang diperoleh dari pengukuran parameter lingkungan perairan di muara Sungai Bengawan Solo disajikan pada Tabel 3. Dari hasil pengamatan suhu selama enam bulan di diperoleh suhu permukaan di perairan muara Sungai Bengawan Solo berkisar 24-32 ${ }^{\circ} \mathrm{C}$, (dengan rata-rata $28,03^{\circ} \mathrm{C}$ ). Kisaran suhu ini termasuk dalam kisaran normal untuk perairan tropis (Hutabarat dan Evans, 1988).

Berdasarkan hasil pengamatan, nilai kecerahan di perairan ini berkisar antara 0,19$36 \%$. Kecerahan tertinggi terdapat di stasiunstasiun yang berada di dekat laut, dan kecerahan terendah terdapat di stasiun sepanjang aliran Sungai Bengawan Solo. Nilai kecerahan perairan di muara Sungai Bengawan Solo semakin meningkat ke arah laut
Hasil pengukuran salinitas yang dilakukan selama 6 bulan di perairan muara Sungai Bengawan Solo, pada semua stasiun berkisar antara 3-29\%o (dengan rata-rata 9,7\%o). Nilai salinitas yang diperoleh dari pengukuran antar stasiun menunjukkan bahwa salinitas semakin meningkat sesuai dengan letak stasiun dari arah sungai sampai ke laut. Sebaran salinitas antar stasiun secara horizontal cenderung meningkat ke arah laut.

Berdasarkan hasil pengamatan kadar nitrat selama 6 bulan menunjukkan konsentrasi nitrat di perairan muara Sungai Bengawan Solo berkisar 0,032-0,998 ppm. Nilai rata-rata kandungan nitrat di perairan muara tersebut adalah 0,4343 ppm. Hal ini menunjukkan tingkat kesuburan perairan di muara sungai ini bervariasi, ada yang cukup subur dan lainnya kurang subur. 
Tabel 3. Nilai rata-rata parameter lingkungan perairan di muara Sungai Bengawan Solo, Gresik, Jawa Timur.

\begin{tabular}{|c|c|c|c|c|c|c|c|c|c|c|c|}
\hline \multirow{2}{*}{$\begin{array}{l}\text { Parameter } \\
\text { (satuan) }\end{array}$} & \multicolumn{11}{|c|}{ Stasiun } \\
\hline & & 1 & 2 & 3 & 4 & 5 & 6 & 7 & 8 & 9 & 10 \\
\hline \multirow[t]{2}{*}{ Suhu $\left({ }^{\circ} \mathrm{C}\right)$} & Rata-rata & 26,67 & 27,33 & 27,75 & 27,67 & 27,92 & 28,5 & 28,5 & 27,92 & 28,25 & 29,75 \\
\hline & Kisaran & $24-29$ & $25-30$ & $25-29,5$ & $26-29$ & $26-30$ & $26-30$ & $26-31$ & $25-29,5$ & $25-30$ & $27-32$ \\
\hline \multirow[t]{2}{*}{$\begin{array}{l}\text { Kecerahan } \\
(\%)\end{array}$} & Rata-rata & 2,67 & 2,15 & 5,29 & 16,03 & 9,27 & 4,09 & 3,25 & 3,3 & 2,79 & 2,68 \\
\hline & Kisaran & $1,1-4,2$ & $\begin{array}{l}0,89- \\
3,98 \\
\end{array}$ & $\begin{array}{l}1,61- \\
11,54\end{array}$ & $\begin{array}{l}2,98- \\
36 \\
\end{array}$ & $\begin{array}{l}1,51- \\
31,24\end{array}$ & $\begin{array}{l}2,5- \\
5,67\end{array}$ & $\begin{array}{l}0,51- \\
8,01 \\
\end{array}$ & $\begin{array}{l}0,47- \\
6,99 \\
\end{array}$ & $\begin{array}{l}0,19- \\
12,35 \\
\end{array}$ & $\begin{array}{l}1,11- \\
7,5 \\
\end{array}$ \\
\hline \multirow[t]{2}{*}{$\begin{array}{l}\text { Arus } \\
(\mathrm{cm} / \text { det.) }\end{array}$} & Rata-rata & 9,02 & 3,59 & 12,53 & 6,13 & 5,93 & 8,89 & 3,91 & 6,01 & 7,43 & 4,04 \\
\hline & Kisaran & $\begin{array}{l}1,09- \\
11,8\end{array}$ & $\begin{array}{l}1,53- \\
6,32 \\
\end{array}$ & $\begin{array}{l}2,26- \\
45,30 \\
\end{array}$ & $\begin{array}{l}3,01- \\
9,5 \\
\end{array}$ & $\begin{array}{l}1,65- \\
12,48 \\
\end{array}$ & $\begin{array}{l}1,65- \\
22,49 \\
\end{array}$ & $\begin{array}{l}1,76- \\
9,32\end{array}$ & $\begin{array}{l}2,14- \\
11,28 \\
\end{array}$ & $\begin{array}{l}2,09- \\
17,98 \\
\end{array}$ & $\begin{array}{l}2,48- \\
6,97 \\
\end{array}$ \\
\hline \multirow[t]{2}{*}{$\begin{array}{l}\text { Salinitas } \\
(\% \mathrm{o})\end{array}$} & Rata-rata & 4,67 & 4,5 & 15,17 & 20,67 & 20,5 & 14,33 & 6 & 3,33 & 4,5 & 3,33 \\
\hline & Kisaran & $3-6$ & $3-6$ & $3-28$ & $4-29$ & $5-28$ & $5-28$ & $3-10$ & $3-4$ & $3-8$ & $3-5$ \\
\hline \multirow[t]{2}{*}{$\begin{array}{l}\text { Nitrat } \\
(\mathrm{ppm})\end{array}$} & Rata-rata & 0,497 & 0,413 & 0,416 & 0,329 & 0,323 & 0,414 & 0,498 & 0,496 & 0,514 & 0,443 \\
\hline & Kisaran & $\begin{array}{l}0,058- \\
0,965 \\
\end{array}$ & $\begin{array}{l}0,077- \\
0,928 \\
\end{array}$ & $\begin{array}{l}0,061- \\
0,998 \\
\end{array}$ & $\begin{array}{l}0,032- \\
0,985 \\
\end{array}$ & $\begin{array}{l}0,047- \\
0,698 \\
\end{array}$ & $\begin{array}{l}0,075- \\
0,936 \\
\end{array}$ & $\begin{array}{l}0,134- \\
0,775 \\
\end{array}$ & $\begin{array}{l}0,152- \\
0,901 \\
\end{array}$ & $\begin{array}{l}0,171- \\
0,928 \\
\end{array}$ & $\begin{array}{l}0,076- \\
0,919 \\
\end{array}$ \\
\hline \multirow[t]{2}{*}{$\begin{array}{l}\text { Fosfat } \\
(\mathrm{ppm})\end{array}$} & Rata-rata & 0,062 & 0,064 & 0,056 & 0,069 & 0,064 & 0,075 & 0,081 & 0,075 & 0,082 & 0,084 \\
\hline & Kisaran & $\begin{array}{l}0,037- \\
0,112 \\
\end{array}$ & $\begin{array}{l}0,046- \\
0,090\end{array}$ & $\begin{array}{l}0,021- \\
0,154 \\
\end{array}$ & $\begin{array}{l}0,011- \\
0,175\end{array}$ & $\begin{array}{l}0,013- \\
0,169 \\
\end{array}$ & $\begin{array}{l}0,019- \\
0,185\end{array}$ & $\begin{array}{l}0,033- \\
0,254\end{array}$ & $\begin{array}{l}0,032- \\
0,16 \\
\end{array}$ & $\begin{array}{l}0,040- \\
0,166\end{array}$ & $\begin{array}{l}0,047- \\
0,150\end{array}$ \\
\hline \multirow[t]{2}{*}{$\begin{array}{l}\text { Silikat } \\
\text { (ppm) }\end{array}$} & Rata-rata & 0,94 & 0,94 & 0,97 & 0,56 & 0,59 & 0,68 & 0,96 & 0,82 & 0,86 & 0,84 \\
\hline & Kisaran & $\begin{array}{l}0,49- \\
1,25 \\
\end{array}$ & $\begin{array}{l}0,52- \\
1,25 \\
\end{array}$ & $\begin{array}{l}0,44- \\
1,16 \\
\end{array}$ & $0,2-1$ & $\begin{array}{l}0,12- \\
1,24 \\
\end{array}$ & $\begin{array}{l}0,24- \\
1,12 \\
\end{array}$ & $\begin{array}{l}0,26- \\
1,59 \\
\end{array}$ & $\begin{array}{l}0,44- \\
1,27 \\
\end{array}$ & $\begin{array}{l}0,51- \\
1,04 \\
\end{array}$ & $\begin{array}{l}0,49- \\
1,01 \\
\end{array}$ \\
\hline
\end{tabular}

Nilai konsentrasi fosfat yang diperoleh dari hasil pengamatan di muara Sungai Bengawan Solo berkisar 0,011-0,254 ppm. Nilai rata-rata kandungan fosfat di perairan tersebut adalah $0,071 \mathrm{ppm}$. Konsentrasi fosfat tertinggi terdapat di Stasiun 10 (0,084 ppm) dan rataan terendah di Stasiun 3 (0,056 ppm). Kandungan fosfat di perairan Kali Porong dan Kali Bengawan Solo tersebut berkisar 0,01-3,76 ppm (Anonim, 1993).

Berdasarkan pengamatan, Silikat di perairan muara Sungai Bengawan Solo berkisar 0,12-1,59 ppm. Nilai rata-rata kandungan Silikat di perairan tersebut adalah $0,816 \mathrm{ppm}$. Nilai rata-rata Silikat tertinggi terdapat di Stasiun 3 (0,97 ppm) dan terendah terdapat pada Stasiun $4 \quad(0,56 \mathrm{p}$ pm). Pada umumnya 
konsentrasi Silikat pada stasiun-stasiun yang berada di muara lebih tinggi dibandingkan dengan stasiun-stasiun yang barada di laut

\section{Pembahasan}

Berdasarkan hasil pengamatan terhadap fitoplankton di perairan muara Sungai Bengawan Solo, jenis yang umum ditemukan adalah Bacillariophyceae, Dinophyceae, Cyanophyceae, Chrysophyceae dan Chlorophyceae. Sedangkan jenis yang paling banyak ditemukan adalah kelas Bacillariophyce. Kondisi demikian menunjukkan bahwa lokasi pengamatan dipengaruhi oleh air laut. Keadaan tersebut dari hasil pengamatan yang menunjukkan bahwa salinitas pada stasiun pengamatan nilainya berkisar 3-29\%o (Tabel 3).

Kondisi demikian juga disampaikan oleh Retnani (2001), pada penelitian yang dilakukan di perairan mangrove Kapuk. Dari penelitian tersebut disampaikan bahwa fitoplankton yang ditemukan di perairan tersebut adalah Bacillariophyceae, Dinophyceae, Cyanophyceae, dan Chlorophyceae. Keadaan demikian, serupa dengan hasil penelitian yang dilaukan Ardiansyah (2002) di perairan Teluk Lampung yang menunjukkan bahwa fitoplankton yang ditemukan di lokasi tersebut adalah Bacillariophyceae, Dinophyceae, Cyanophyceae, dan Chlorophyceae. Kelas Bacillariophyceae (Skeletonema sp, Leptocylindicus sp, Guinardi sp, dan Caetoceros sp.) merupakan jenis yang ditemukan dalam jumlah dalam jumlah paling banyak dibandingkan dengan jenis yang lain.

$$
\text { Syadiah (2002) melaporkan }
$$

penelitiannya di Teluk Lampung. Bardasarkan penelitian tersebut ditemukan jenis Bacillariophyceae sebagai organisma yang paling banyak ditemukan, kemudian diikuti jenis-jenis yang lain, yaitu Dinophyceae, Cyanophyceae, dan Chlorophyceae. Lerbih lanjut, keadaan demikian disampaikan oleh Komariah (2002) yang telah melakukan penelitian di Teluk Jakarta. Berdasarkan hasil penelitian tersebut, jenis-jenis fitoplankton yang ditemukan juga terdiri atas Bacillariophyceae, Dinophyceae, Cyanophyceae, dan Chlorophyceae. Nontji (1987) menyatakan bahwa fitoplankton yang biasa tertangkap dengan jaring plankton net tergolong dalam 3 kelompok, yaitu Diatom (Bacillariophyceae), Dinoflagellata (Dinophyceae) dan alga biru (Cyanophyceae).

Berdasarkan kelimpahan rata-rata fitoplankton di muara Sungai Bengawan Solo (Gambar 3) dapat dilihat bahwa kelimpahan fitoplankton di perairan muara tersebut didominasi kelas Bacillariophyceae (Diatom) terutama jenis Skeletonema sp dan Chaetoceros sp yang terdapat pada pada seluruh stasiun pengamatan (dengan kelimpahan rata-rata 2684 ind/l dan 1854 ind/l per stasiun). Kelimpahan fitoplankton jenis ini secara horizontal semakin meningkat ke arah laut (Gambar 3). Konsentrasi silikat yang rendah (pada stasiun yang berada di dekat laut) menunjukkan perkiraan pemanfaatan silikat di daerah ini tinggi sehingga kelimpahan fitoplankton kelas Diatom tersebut ditemukan 
melimpah dibandingkan stasiun yang berada di sekitar muara. Konsentrasi silikat yang rendah di perairan muara Sungai Bengawan Solo diperkirakan merupakan salah satu faktor yang mempengaruhi kelimpahan fitoplankton jenis Diatom rendah, meskipun komposisi fitoplankton kelas ini lebih besar daripada kelaskelas lainnya yang ditemukan di perairan ini. Menurut Kennish (1990), konsentrasi silikat seringkali mempengaruhi kelimpahan dan produktivitas fitoplankton terutama jenis Diatom. Disamping itu, siklus akan mempengaruhi lingkungan perairan termasuk produktivitas primer (Basmi, 1999).

Fluktuasi salinitas dan arus diduga berhubungan juga dengan keberadaan fitoplankton jenis tersebut. Menurut Davis (1955) distribusi horizontal fitoplankton di suatu perairan tidak merata, meskipun arealnya relatif berdekatan dan berasal dari massa air yang sama. Hal ini disebabkan oleh bermacammacam faktor diantaranya arus, salinitas, pengaruh pasang surut, dan keberadaan unsur hara.

Kelimpahan fitoplankton selama pengamatan menunjukan bahwa pada musim peralihan (Mei) dan musim timur (Juni), kelimpahan fitoplankton ditemukan lebih besar. Hal ini dipengaruhi oleh kondisi lingkungan perairan setempat seperti nitrat, silikat, salinitas, dan kecepatan arus. Salinitas dan kecepatan arus pada bulan tersebut lebih tinggi dari bulan Januari-April. Hal ini berbanding terbalik dengan konsentrasi nitrat dan silikat yang menurun. Konsentrasi zat hara yang menurun menunjukan pemanfaatan zat hara tinggi sehingga kelimpahan fitoplankton meningkat (Tabel 3).

Hasil penelitian Retnani (2001) menyampaikan bahwa kelimpahan fitoplankton di perairan Muara Angke, Jakarta berkisar 28626256 ind./1. Keadaan demikian menggambarkan bahwa kelimpahan fitoplankton berada dalam kisaran hasil penelitian Retnani (2001).

\section{KESIMPULAN}

Komposisi jenis fitoplankton yang ditemukan di perairan Muara Sungai Bengawan Solo terdiri dari 5 kelas dan 32 jenis fitoplankton yaitu kelas Diatom, Cyanophyceae, Crysophyceae, Chlorophyceae, dan Dinophyceae, dimana komposisi kelas Bacillariophyceae (Diatom) mendominasi perairan ini. Jenis fitoplankton yang dominan adalah Skeletonema $\mathrm{sp}$ dan Chaetoceros sp. Secara horizontal, komposisi fitoplankton (terutama kelas Diatom) semakin meningkat ke muara dan menurun kembali ke arah laut.

Kelimpahan fitoplankton di perairan Muara Sungai Bengawan Solo berada dalam kisaran antara 1034-19726 ind/l. Ada kecenderungan semakin ke arah laut, kelimpahan fitoplankton semakin meningkat dan kemudian mulai menurun kembali ketika menjauhi pantai. Hal ini terlihat dari kelimpahan fitoplankton di daerah sungai berkisar antara 1034-3017 ind/l, di muara sebesar 3979-19726 ind/l dan di laut sebesar 4206-7877 ind/l. 
Nilai indeks keanekaragaman di perairan ini bervariasi dimana pada saat tertentu perairan ini didominasi oleh suatu jenis fitoplankton dan pada waktu lainnya penyebaran fitoplankton merata tidak ada suatu jenis fitoplankton yang mendominasi. Nilai Indeks keanekaragaman berkisar antara 0.29-2.24 dengan keseragaman dan dominansi di perairan ini tergolong rendah hingga tinggi $(\mathrm{E}=0.18-0.97$ dan $\mathrm{C}=0.13-0.88)$.

\section{DAFTAR PUSTAKA}

Adriansyah, R. 2002. Ruktur Distribusi dan struktur komunitas fitoplankton di perairan Teluk Lampung, Provinsi Lampung. Program Studi Ilmu Kelautan, Fakultas Perikanan dan Ilmu Kelautan, Institut Pertanian Bogor. Bogor. Hal.

Anonim. 1993. Laporan Penelitian Kimia pada Penelitian Pencemaran Kali Porong dan Kali Bengawan Solo. Puslitbang Oseanologi - LIPI, Jakarta.

Arinardi OH. 1997. Kisaran Kelimpahan dan Komposisi Plankton Predominan di Perairan Kawasan Timur Indonesia. Pusat Penelitian dan Pengembangan Oseanologi. LIPI, Jakarta.

Basmi J. 1999. Planktonologi: CrysophytaDiatom Penuntun Identifikasi. Fakultas Perikanan dan Ilmu Kelautan. IPB.

Berwick NK. 1983. Guidlines for the Analysis of Biophysical Impact to Tropical Marine Resources. The Bombay Natural History Society Centenary Seminar Conservation in Developing Country.

Birowo S, Ukloseja H. 1976. Sifat-sifat Oseanografi Perairan Pantai Indonesia. Paper pada Symposium Pendekatan Ekologis untuk Perairan Pesisir Pertemuan II Bogor. 29-31 Maret 1976.

Dharma AI, Suryana, Hadikusumah. 1986. Penelitian Oseanografi-Fisika di Perairan DAS Bengawan Solo November 1984 dan September 1985. Pusat Penilitian dan
Pengembangan Oseanologi. LIPI, Jakarta. 1986.

Davis CC. 1955. The Marine and Fresh Water Plankton. Michigan State University Press. USA. 562 p.

Hutabarat S, Evans M, Stewart. 1988. Pengantar Oseanografi. Direktorat Jenderal Pendidikan Tinggi. Jakarta.

Kennish MJ. 1990. Ecology of Estuary. Vol II. Biological Aspect. CRC Press, Inc., United States

Komariah, H. 2002. Struktur komunitas fitoplankton di perairan Teluk Jakarta. Program Studi Ilmu Kelautan, Fakultas Perikanan dan Ilmu Kelautan, Institut Pertanian Bogor. Bogor. 46 hal.

Krebs CJ. 1989. Ecological Methodology. Harper Collins Publishers. New York.

Legendre L, Legendre P. 1983. Numerical Ecology. Elvesier Scientific Publishing Company.

Magurran, A. E. 1955. Ecological Diversity and Its Measurement. Princeton University Press. United state of America.

Mevita, B. 2001. Sebaran biomasa klorofil A (fitoplankton) permukaan di perairan Teluk Lampung pada Bulan Januari, Februari, dan Mei 2001. Program Studi Ilmu Kelautan, Fakultas Perikanan dan Ilmu Kelautan, Institut Pertanian Bogor. Bogor. Hal.

Nybakken JW. 1988. Biologi Laut: Suatu pendekatan ekologis. Alih bahasa: M. Eidman, Koesoebiono, D.G. Bengen, H. Malikusworo dan Sukristijono. PT. Gramedia, Jakarta.

Odum EP. 1971. Fundamental of Ecology. WB. Saunders Company. London.

Rismawan, I. 2000. Stnruktur komunitas dan sebaran horizontal fitoplankton di perairan Muara Angke dan Sunda Kelapa. Program Manajemen Sumberdaya Perairan, Fakultas Perikanan dan Ilmu Kelautan, Institut Pertanian Bogor. Bogor. Hal.

Ross DA. 1970. Introduction to Oceanography. Meredith Corporation. New York. 
Syadiah, N. 2002. Struktur komunitas fitoplankton di perairan Teluk Lampung pada Bulan Juli, September dan November 2001. Program Studi Ilmu Kelautan, Fakultas Perikanan dan Ilmu
Kelautan, Institut Pertanian Bogor. Bogor. Hal.

Yamaji I. 1979. Illustration of the Marine plankton of Japan. Haikusha Publishing co Ltd. Osaka, Japan. 